\title{
VITREOUS POTASSIUM CONCENTRATION AS A PREDICTOR OF POSTMORTEM INTERVAL IN SEVERE BURN DEATHS AT ALEXANDRIA MORTUARY
}

\author{
Hamed El Sawaf ${ }^{2}$, Marcelle Ramsis ${ }^{1}$, Nermeen Adly ${ }^{1}$, Afaf Abdelkader ${ }^{\text {, }}$ \\ Rabab F Hindawy ${ }^{1,}$ Asmaa Y. A. Hussein ${ }^{1}$ \\ ${ }^{1}$ Forensic Medicine and Clinical Toxicology Department, Faculty of Medicine, Benha \\ University, Benha, Egypt \\ ${ }^{2}$ Mortuary of Alexandria, Medicolegal department, Medicolegal Authority, Ministry of \\ justice, Egypt
}

marcelle.ramsis@fmed.bu.edu.eg nermeen hassan@fmed.bu.edu.eg afaf abdelkader @fmed.bu.edu.eg rabab.hindawy@fmed.bu.edu.eg asmaa.yassen@fmed.bu.edu.eg

\section{ABSTRACT}

Background: Postmortem interval estimation (PMI) is an important goal in forensic medicine. Aim: to estimate PMI using a scoring method for postmortem changes; hypostasis, rigidity and corneal turbidity in burn cases, potassium $\left(\mathrm{K}^{+}\right)$in vitreous humor (VH) and serum and compare accuracy of thanatochemistry and scoring method for postmortem changes in estimation of PMI. Methods: The study was conducted from May 2017 to May 2018, 50 burn cases where autopsy confirmed the cause of death as severe burns and another 50 control cases. Physical postmortem changes were assessed and numerically scored. The $\mathrm{VH}\left(\mathrm{K}^{+}\right)$and serum levels were measured. Data were statistically analyzed and linear regression analysis was used to obtain equations for calculation of PMI. Results: All studied variables in the present study were significantly correlated with PMI; highest correlation coefficient in control and burn groups was for $\mathrm{VH}\left(\mathrm{K}^{+}\right)$level, followed by corneal turbidity and serum $\mathrm{K}^{+}$then rigidity in burn groups, but in control groups the highest correlation coefficient was for $\mathrm{VH}\left(\mathrm{K}^{+}\right)$and serum levels, followed by rigidity then corneal turbidity and lastly hypostasis. All equations obtained from the present study can predict PMI but with different levels of accuracy. Conclusion: The scoring method for physical postmortem changes was proved to be more valuable in PMI estimation than thanatochemistry.

Keyword: Burn, vitreous humor, potassium $(\mathrm{K}+)$, postmortem interval

\section{INTRODUCTION}

A burn is a type of injury to skin, or other tissues, caused by heat, chemicals, electricity, friction, or radiation. Burns are classified as burns by flame, contact, chemical (caused by acids or alkalis), electric, and scalding; scald burns represent the most frequent group in the world (Pounder, 2005 and Herndon, 2012).

According to the World Health Organization (WHO), 238,000 individuals died due to fire-related burns in the year 2000, and $95 \%$ of these deaths occurred in low and middleincome countries. About 1.25 million 
burn injuries occur yearly in the USA. While there are about 250,000 people are burned yearly in United Kingdom (Karter 2006).

Burn injuries have long been described as among the most serious and public problem that may afflict a human being, 265000 deaths occur each year from fire alone. Burns are the 4th most common type of trauma worldwide, following traffic accidents, falls and interpersonal violence (Church et al., 2006 ; Karter, 2011 and Mazumdar \& Patowary, 2013).

In Egypt, burns and burn deaths, considered as a significant problem. Burn is one of the leading causes of morbidity and mortality among Egyptians, they constitute $2.66 \%$ of the total deaths coming for autopsy at mortuary. In, about $67.1 \%$ of the victims were in the age group of 10-50 years. The higher incidence of burn deaths among males, but women in childbearing age were reported to be at a higher risk (Afify et al., 2012 and Taha, et al., 2018).

Time since death (TSD) is an important goal to the forensic expert and also to the investigating agency, if determined with measurable accuracy. Burn cases bodies are challenging to forensic pathologists, in burn death, most useful elements for the estimation of time since death, such as rigor mortis, algor mortis and livor mortis have great variation and some of them cannot by demonstrated (Rathinam et al., 2015 and Whitaker, 2017).

However, accurate TSD determination is extremely difficult as timings of onset and the rates of postmortem changes are usually governed by unpredictable endogenous and exogenous factors, so there has been an increasing interest in the use of vitreous humors especially vitreous potassium for biochemical analysis for determination of TSD. In burn death, the vitreous $\mathrm{K}+$ and rate of it is increasing not well studied but scanty previous results showed that the vitreous $\mathrm{K}+$ and rate of it is increasing higher in burn than the other cases (Garg et al., 2004; Ahi \& Garg, 2011;Rathinam et al., 2015 and Kulkarni et al., 2016).

Therefore, the present study was planned to determine the TSD among burn injury cases from ordinary methods (post mortem changes) and other methods because the high incidence of burn death in Egypt and difficulty of determination of TSD especially in severe burn.

\section{AIM OF THE WORK}

The present work was done to

- Estimate the changes in the vitreous $\mathrm{K}^{+}$concentration in relation to PMI among severe burns cases.

- Study correlation between determination PMI by vitreous $\mathrm{K}^{+}$ concentration and ordinary methods (post mortem changes as hypostasis, rigor mortis and corneal turbidity) among severe burn cases and compare their accuracies.

- To formulate equations for calculation of PMI from changes in levels of $\mathrm{K}^{+}$and $\mathrm{PM}$ changes in the study subjects.

\section{SUBJECTS \& METHODS}

\section{* Subjects:}

This study was prospectively carried out at the mortuary of Alexandria medicolegal department, Ministry of justice on cases of deaths presented to 
mortuary from May 2017 to May 2018. An official permission has been taken from the director of the Alexandria Medico legal Authority.

This study was accepted by the local research Ethical Committee, Banha Faculty of Medicine, Benha University.

Inclusion criteria (Gilbert et al., 2005; Luna, 2009 and Salam et al., 2012):

1- Cases where autopsy confirm the cause of death as severe burns in burn cases.

2- Cases where exact time of death was known and it correlated with postmortem changes like postmortem appearance and situation of rigor mortis, site and color of postmortem hypostasis and corneal turbidity.

3- Cases with age more than 18 years as vitreous potassium level that has not been established as a reliable method of estimating postmortem interval in children below the 18 years. This may be explained by the fact that the diameter of the globe, which represents the diffusion distance, through which the diffusion of various biochemical constituents from the retina to the $\mathrm{VH}$ in the postmortem period occur is smaller in children than in adults. Consequently, the PM constituents are higher in children. Therefore, the formulae used in PMI prediction for adults may not be suitable for use in children since there is a systematic overestimation of PMI owing to larger concentrations.

Exclusion criteria (Madea \& Henssge, 2003):

1- Cases with burns other than thermal cause.
2- Cases whose time of death on enquiry from different sources were found to differ by $> \pm 15 \mathrm{~min}$.

3- Cases with known or suspected ocular diseases, vitreous fluid cloudy, discolored or contaminated with blood, trauma to head. These cases were excluded from the study to preserve the integrity of the eye globe as vitreous values are valid only when obtained from an intact globe.

4- Cases with insufficient vitreous humor for the biochemical analyses.

5- Cases who were given electrolytes, diuretics prior death or Cases with known electrolyte disturbances prior to death.

6- Cases have chronic disease like renal or hepatic failure was also excluded in this study. This could be attributed to the fact that autolysis and metabolic postmortem processes, as postmortem increase of potassium level in vitreous humor, is influenced by chronic diseases.

This study was prospectively carried out on 100 cases of deaths presented to mortuary of Alexandria from May 2017 to May 2018.

Fifty of these cases are burn cases, where autopsy confirmed the cause of death as severe burns according to American Burn Association severity classification (Mahadevan \& Garmel, 2012).

Another 50 cases as control cases of known time since death (TSD) were chosen randomly from non-burn deaths. 


\section{Cases data:}

Data regarding Time of death, age, sex, types, degree and extent of burn was gathered from police records, hospital records or from eye witnesses, relatives, friends, and attendants of the deceased.All personal data has been kept anonymous to ensure confidentiality of data.

\section{Cases Grouping}

Each control and burn cases were grouped into three groups according to TSD

\section{Control groups}

Group (A): cases with TSD ranging from zero up to less than $12 \mathrm{~h}$.

Group (B): cases with TSD ranging from $12 \mathrm{~h}$ up to less than $24 \mathrm{~h}$.

Group (C): cases with TSD ranging from $24 \mathrm{~h}$ up to $36 \mathrm{~h}$.

\section{Burn groups}

Group (D): burn cases with TSD ranging from zero up to less than $12 \mathrm{~h}$.
Group (E): burn cases with TSD ranging from $12 \mathrm{~h}$ up to less than $24 \mathrm{~h}$.

Group (F): burn cases with TSD ranging from $24 \mathrm{~h}$ up to $36 \mathrm{~h}$.

\section{Methods:}

The following data was studied

I. Demographic data: age and sex

\section{Assessment of external postmortem changes:}

On external postmortem examination, the development of hypostasis, rigidity and corneal turbidity were categorized, and each phase was designated and numerically scored to estimate TSD, the post mortem rigidity was categorized into 5 phases according to its onset, development and resolution.

The hypostasis was categorized into 4 phases according to its appearance and movement by thumb pressure and the corneal turbidity was categorized into 4 phases according to its degree of clouding (Table 1).

Table (1): Scores for the development of the postmortem changes (rigidity, hypostasis and corneal turbidity) (Honjyo et al., 2005 and Salam et al., 2012):

\begin{tabular}{|l|l|l|l|}
\hline Score & Corneal turbidity & Hypostasis & Rigidity \\
\hline 1 & No clouding & Before appearance & Before onset \\
\hline 2 & Slight clouding & $\begin{array}{l}\text { Easy to remove by } \\
\text { thumb pressure }\end{array}$ & Partial development \\
\hline 3 & Moderate clouding & $\begin{array}{l}\text { Hard to remove by } \\
\text { thumb pressure }\end{array}$ & Complete development \\
\hline 4 & Strong clouding & $\begin{array}{l}\text { Unable to remove by } \\
\text { thumb pressure }\end{array}$ & Partial resolution \\
\hline 5 & & & Complete resolution \\
\hline
\end{tabular}


III. Analysis of potassium (Vaitla and Vani, 2017):

a. Analysis done immediately after aspiration of sample, each sample was centrifuged at 3000 r.p.m for 10 minutes and the supernatant fluid was used for determination of potassium by ion selective electrode method.

b. The serum was separated immediately by centrifugation and analysis done immediately by ion selective electrode.

The vitreous humor potassium and serum potassium analyses were carried out immediately post extraction on the same day of collection.

\section{Samples collection}

1. In the present study, vitreous humor $(\mathrm{VH})$ samples were withdrawn from the right eye to avoid the significant difference in potassium $\left(\mathbf{K}^{+}\right)$ concentration between the two eyes of the same subject that was proved by Pounder et al., (1998).

One $\mathrm{ml}$ of $\mathrm{VH}$ was obtained, from the right eye of each case at the beginning of autopsy, by sclera puncture near the outer canthus, to avoid the change of the eye shape, using a $10 \mathrm{ml}$ syringe and number 20-gauge needle from the eye. The lids were retracted, so that the hole is covered when the lids were released. Fluid was withdrawn slowly keeping the tip of the needle in the center of the globe to avoid dislodging the retina. Any specimen that

is not crystal clear was rejected (Saukko, 2004 and Madea \& Alexander, 2006).
2. At the time of autopsy examination, venous blood sample (5 $\mathrm{ml}$ ) was collected from femoral vein by inserting the needle at about two finger breadth below the inguinal ligament at middle point marked between the anterior superior iliac spine and the symphysis (Millo et al., 2008).

\section{Statistical analysis}

Data were fed to the computer and analyzed using IBM SPSS software package version 20.0. (Armonk, NY: IBM Corp). Using number and percent to describe qualitative data (Kirkpatrick and Feeney, 2012)

- Arithmetic mean, standard deviation and student $\mathrm{t}$ - test, chi square $(\chi 2)$, ANOVA (F-test) and Fisher exact test.

- Monte Carlo (MC) correction

- Kruskal Wallis test

- Spearman coefficient

- Linear regression analysis

- Pearson correlation coefficients

- calculation of adjusted R2 using Stein formula

- post hoc test

The accepted level of significance was stated at $0.05 \quad(\mathrm{P}<0.05$ was considered significant) (Khothari, 2004). 


\section{RESULTS}

Table (2): Comparison between the six studied groups according to demographic data (Age and Sex)

\begin{tabular}{|c|c|c|c|c|c|c|c|c|c|c|c|c|c|c|}
\hline & \multicolumn{6}{|c|}{$\begin{array}{c}\text { Control cases TSD } \\
\quad(n=50)\end{array}$} & \multicolumn{6}{|c|}{$\begin{array}{l}\text { Burn cases TSD } \\
\quad(n=50)\end{array}$} & \multirow{3}{*}{$x^{2}$} & \multirow{3}{*}{$p$} \\
\hline & \multicolumn{2}{|c|}{$\begin{array}{l}\text { Group A } \\
(n=12)\end{array}$} & \multicolumn{2}{|c|}{$\begin{array}{l}\text { Group B } \\
(n=17)\end{array}$} & \multicolumn{2}{|c|}{$\begin{array}{l}\text { Group C } \\
(n=21)\end{array}$} & \multicolumn{2}{|c|}{$\begin{array}{l}\text { Group D } \\
(n=12)\end{array}$} & \multicolumn{2}{|c|}{$\begin{array}{l}\text { Group E } \\
(n=20)\end{array}$} & \multicolumn{2}{|c|}{$\begin{array}{l}\text { Group F } \\
(n=18)\end{array}$} & & \\
\hline & No. & $\%$ & No. & $\%$ & No. & $\%$ & No. & $\%$ & No. & $\%$ & No. & $\%$ & & \\
\hline \multicolumn{15}{|c|}{ Age decade } \\
\hline Second & 3 & 25.0 & 3 & 17.6 & 3 & 14.3 & 2 & 16.7 & 3 & 15.0 & 3 & 16.7 & & \\
\hline Third & 4 & 33.3 & 5 & 29.4 & 6 & 28.6 & 4 & 33.3 & 6 & 30.0 & 5 & 27.8 & & \\
\hline Fourth & 3 & 25.0 & 3 & 17.6 & 4 & 19.0 & 1 & 8.3 & 3 & 15.0 & 2 & 11.1 & 5.302 & 1.000 \\
\hline Fifth & 1 & 8.3 & 3 & 17.6 & 5 & 23.8 & 3 & 25.0 & 5 & 25.0 & 5 & 27.8 & & \\
\hline Sixth & 1 & 8.3 & 3 & 17.6 & 3 & 14.3 & 2 & 16.7 & 3 & 15.0 & 3 & 16.7 & & \\
\hline \multicolumn{15}{|l|}{ Sex } \\
\hline Male & 6 & 50.0 & 6 & 35.3 & 7 & 33.3 & 4 & 33.3 & 7 & 35.0 & 6 & 33.3 & 1.191 & 0.946 \\
\hline Female & 6 & 50.0 & 11 & 64.7 & 14 & 66.7 & 8 & 66.7 & 13 & 65.0 & 12 & 66.7 & & \\
\hline
\end{tabular}

The age of autopsy cases was ranged from 18 to 58 years. Most of the cases were females.

Table (3): Distribution of control and Burn cases according to PMI

\begin{tabular}{|c|c|c|c|c|c|c|c|c|}
\hline \multirow{2}{*}{ PMI } & \multicolumn{3}{|c|}{$\begin{array}{l}\text { Control autopsy cases } \\
\qquad(\mathbf{n}=\mathbf{5 0})\end{array}$} & \multirow{2}{*}{$\begin{array}{l}\text { Total } \\
(\mathbf{n}=\mathbf{5 0})\end{array}$} & \multicolumn{3}{|c|}{$\begin{array}{l}\text { Burn autopsy cases } \\
\quad(\mathbf{n}=\mathbf{5 0})\end{array}$} & \multirow{2}{*}{$\begin{array}{l}\text { Total } \\
(\mathbf{n}=\mathbf{5 0})\end{array}$} \\
\hline & $\begin{array}{c}\text { Group A } \\
(\mathbf{n}=12)\end{array}$ & $\begin{array}{c}\text { Group B } \\
(\mathbf{n}=17)\end{array}$ & $\begin{array}{c}\text { Group C } \\
(\mathrm{n}=21)\end{array}$ & & \begin{tabular}{|c|}
$\begin{array}{c}\text { Group D } \\
(\mathrm{n}=12)\end{array}$ \\
\end{tabular} & $\begin{array}{l}\text { Group E } \\
(\mathbf{n}=\mathbf{2 0})\end{array}$ & $\begin{array}{l}\text { Group F } \\
(n=18)\end{array}$ & \\
\hline Min. - Max. & $3.50-11.0$ & $12.0-23.50$ & $24.0-35.0$ & $3.50-35.0$ & $5.50-12.0$ & $12.0-24.0$ & $24.50-36.0$ & $5.5-36.0$ \\
\hline Mean \pm SD. & $5.54 \pm 2.75$ & $16.59 \pm 3.68$ & $27.55 \pm 3.47$ & $18.54+9.4$ & $8.54 \pm 2.06$ & $18.40 \pm 3.88$ & $29.33 \pm 4.0$ & $19.97 \pm 8.81$ \\
\hline Median & 4.13 & 15.0 & 27.0 & 20.50 & 8.25 & 18.25 & 29.0 & 21.0 \\
\hline
\end{tabular}

The reported postmortem intervals in the present study ranged from $3.5 \mathrm{~h}$ to $35 \mathrm{~h}$ in control groups with a mean of $(18.54 \pm 9.41)$ and ranged from $5.5 \mathrm{~h}$ to36.0h in burn groups with a mean of $(19.97 \pm 8.81)$. 


\section{Physical postmortem changes}

Table (4): Correlation between TSD and different parameters scores (Hypostasis, Rigidity and Corneal opacity) in control and burn cases

\begin{tabular}{|c|c|c|c|c|}
\hline \multirow{2}{*}{ Pm changes } & \multicolumn{4}{|c|}{ TSD } \\
\cline { 2 - 5 } & \multicolumn{2}{|c|}{$\begin{array}{c}\text { Control cases } \\
(\mathbf{n}=\mathbf{5 0})\end{array}$} & \multicolumn{2}{c|}{$\begin{array}{c}\text { Burn cases } \\
(\mathbf{n}=\mathbf{5 0})\end{array}$} \\
\cline { 2 - 5 } & $\mathbf{r}_{\mathrm{s}}$ & $\mathbf{p}$ & $\mathbf{r}_{\mathrm{s}}$ & $\mathbf{p}$ \\
\hline Hypostasis score & 0.669 & $<0.001^{*}$ & 0.228 & $>0.05$ \\
\hline Rigidity score & 0.909 & $<0.001^{*}$ & 0.789 & $<0.001^{*}$ \\
\hline Corneal opacity score & 0.899 & $<0.001^{*}$ & 0.886 & $<0.001^{*}$ \\
\hline
\end{tabular}

* Spearman coefficient was statistically highly significant $\mathrm{p}<0.001$

Present study demonstrated a highly significant correlation between each of hypostasis, rigidity and corneal turbidity and TSD in control cases using Spearman's rho correlation coefficient with $(\mathrm{p}<0.001)$ for different parameters, while in burn cases demonstrated also a highly significant correlation between each of rigidity and corneal turbidity with TSD in burn group but no significant correlation between hypostasis and TSD was noticed.
Postmortem $\mathrm{K}^{+}$concentration in VH and serum:

Correlation between (TSD) in control and burn cases and $\mathrm{K}^{+}$ concentration in vitreous and serum

The $\mathrm{VH}\left(\mathrm{K}^{+}\right)$and serum $\mathrm{K}^{+}$ concentration values of all control and burn cases were plotted against TSD in (Fig. 1, 2). It reveals a linear relationship. The $\mathrm{K}^{+}$levels in $\mathrm{VH}$ and serum increased in a regular fashion with an

TSD. 


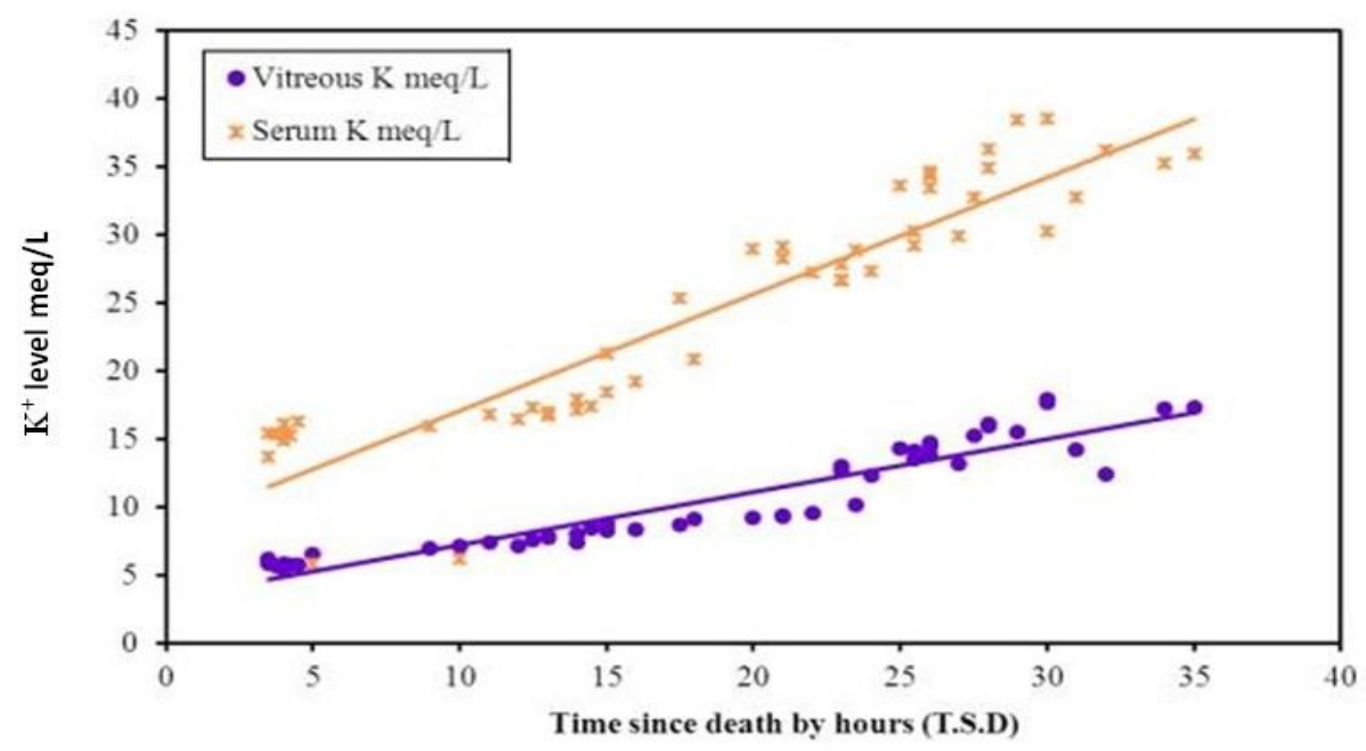

Figure (1):Scatter plot showing correlation between TSD with $\mathrm{VH} \mathrm{K}^{+}$meq/L and Serum $\mathrm{K}^{+} \mathrm{meq} / \mathrm{L}$ in control cases.

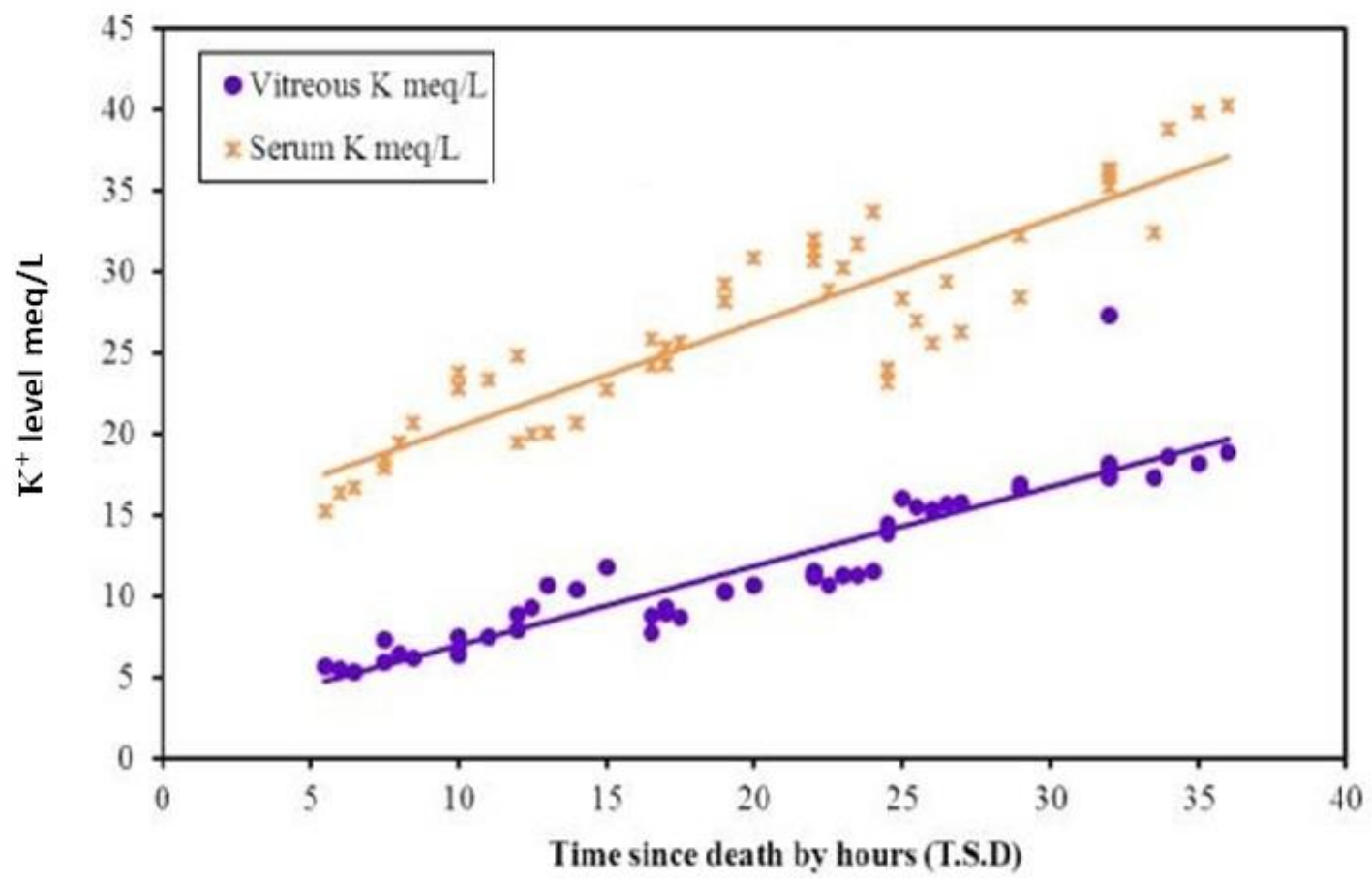

Figure (2): Scatter plot showing correlation between TSD and $\mathrm{VH} \mathrm{K} \mathrm{K}^{+}$meq/L and Serum $\mathrm{K}^{+} \mathrm{meq} / \mathrm{L}$ in burn cases. 
Table (5): Correlation between Time since death by hours (T.S.D) and different parameters in control and burn cases

\begin{tabular}{|l|c|c|c|c||}
\hline \multirow{2}{*}{} & \multicolumn{4}{|c|}{ Time since death by hours (T.S.D) } \\
\cline { 2 - 5 } & \multicolumn{2}{|c|}{$\begin{array}{c}\text { Control cases TSD } \\
(\mathrm{n}=50)\end{array}$} & \multicolumn{2}{c|}{$\begin{array}{c}\text { Burn cases TSD } \\
(\mathrm{n}=50)\end{array}$} \\
\cline { 2 - 5 } & $\mathrm{r}_{\mathrm{s}}$ & $\mathrm{p}$ & $\mathrm{r}_{\mathrm{s}}$ & $\mathrm{p}$ \\
\hline Vitreous K meq/L & 0.966 & $<0.001^{*}$ & 0.966 & $<0.001^{*}$ \\
\hline Serum K meq/L & 0.959 & $<0.001^{*}$ & 0.865 & $<0.001^{*}$ \\
\hline Regidity score & 0.909 & $<0.001^{*}$ & 0.789 & $<0.001^{*}$ \\
\hline Corneal opacity score & 0.899 & $<0.001^{*}$ & 0.886 & $<0.001^{*}$ \\
\hline Hypostasis score & 0.669 & $<0.001^{*}$ & 0.228 & 0.111 \\
\hline \hline
\end{tabular}

$\mathrm{r}_{\mathrm{s}}$ : Spearman coefficient $\quad *$ : Statistically high significant at $\mathrm{p} \leq 0.001$

All the studied variables in control groups were high significantly correlated with PMI, and in burn groups all studied variables were high significantly correlated with PMI except hypostasis. The highest correlation coefficient in control and burn groups was for $\mathrm{K}^{+}$level in $\mathrm{VH}$.

\section{Equations for prediction of TSD using PM changes with $\mathrm{K}^{+}$:}

As regard to control and burn cases, different regression equations for prediction of TSD were obtained using each of the scoring system of the three postmortem changes; hypostasis, rigidity and corneal turbidity, vitreous $\mathrm{K}^{+}$with their estimates of reliability (R2), where the greater the value of $\mathrm{R} 2$, the higher the accuracy of the equation. Using Stein formula, adjusted R2 was calculated, which is a measure for the predictive power of the equation in any other sample if derived from the same population. It was used as a mean to cross validate the resulted equations, using data of the study sample, the higher the value of adjusted R2, the more the accuracy of the equation. The difference in prediction power between the R2 and the adjusted R2 of the equation is called percent shrinkage which is a measure for cross validation of the equation. 
- Equations for prediction of TSD in control cases

Table (6): Regression equation for prediction of TSD in control cases.

\begin{tabular}{|c|c|c|c|c|c|c|}
\hline no & Equation & $\mathbf{R 2}$ & $\begin{array}{l}\text { Adjusted } \\
\text { R2 }\end{array}$ & \% Shrinkage & $\mathbf{F}$ & $\mathbf{P}$ \\
\hline 1 & TSD $=-5.419+($ Vitreous K x2.273 $)$ & 0.882 & 0.880 & 0.2 & 359.197 & $<0.001^{*}$ \\
\hline 2 & $\begin{array}{c}\text { TSD }=-11.636+(\text { Vitreous K x1.364 }) \\
+(\text { Rigidity } \times 3.835)\end{array}$ & 0.962 & 0.961 & 0.1 & 601.005 & $<0.001 *$ \\
\hline 3 & $\begin{array}{c}\text { TSD }=-11.028+(\text { Vitreous K x 1.148 }) \\
+(\text { Rigidity } \times 3.409)+ \\
(\text { Corneal opacity } \times 1.369)\end{array}$ & 0.968 & 0.966 & 0.2 & 460.625 & $<0.001 *$ \\
\hline 4 & 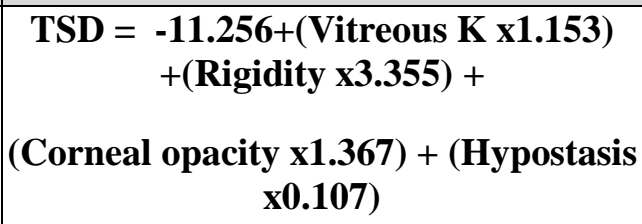 & 0.968 & 0.965 & 0.3 & 338.092 & $<0.001 *$ \\
\hline
\end{tabular}

* $\mathrm{P}$ values for ANOVA test f-test was statistically highly significant at $\mathrm{p}<0.001$

This table demonstrates that All obtained equations were highly significant and can predict TSD but with different R2. The four equations showed variable predictive power with the best for Equation3, 4and least in equation 1. In the present study, the least \% of shrinkage was for Equation (2).

Table (7): Mean values and 95\% confidence interval (CI) of absolute deviation of residual of equations of control cases

\begin{tabular}{|c|c|c|c|}
\hline equation & Mean value of absolute deviation of residual & $\mathbf{9 5} \% \mathbf{C I}$ & $\mathbf{9 5} \% \mathbf{C I}$ \\
$\mathbf{L}$ & & 2.0 & 3.11 \\
\hline Equation 1 & 2.56 & 0.93 & 1.65 \\
\hline Equation 2 & 1.29 & 0.77 & 1.48 \\
\hline Equation 4 & $\mathbf{1 . 1 2}$ & 0.77 & 1.48 \\
\hline
\end{tabular}

The least mean of absolute deviations for the residuals between the actual and the estimated values of TSD were for equation ( 3 and 4) followed by equation (2). 
Table (8): Pairwise comparisons of the differences between the mean values of the absolute deviations for the residuals of the four equations in control cases

\begin{tabular}{|c|c|c|c|c|}
\hline & Equation 1 & Equation 2 & Equation 3 & Equation 4 \\
\hline $\begin{array}{c}\text { Equation 1 } \\
\text { value }\end{array}$ & - & & & \\
\hline $\mathrm{p}$ & - & & & \\
\hline $\begin{array}{c}\text { Equation 2 } \\
\text { value }\end{array}$ & 1.268 & - & & \\
\hline $\begin{array}{c}\text { Difference } \\
\mathrm{p}\end{array}$ & $<0.001^{*}$ & & & \\
\hline $\begin{array}{c}\text { Equation 3 } \\
\text { vifference } \\
\text { value }\end{array}$ & 1.433 & 0.166 & & \\
\hline $\mathrm{p}$ & $<0.001^{*}$ & 0.064 & & \\
\hline Equation 4 & & & & \\
\hline $\begin{array}{c}\text { Difference } \\
\text { value }\end{array}$ & 1.433 & 0.165 & 0.00 & \\
\hline $\mathrm{p}$ \\
\hline
\end{tabular}

*p value for Post Hoc Test (LSD) for ANOVA with repeated measures for comparing between each two equations was statistically highly significant at $p<0.001$

The pairwise comparisons between the mean absolute deviation for the residuals between the actual and the estimated values of TSD obtained from each of the four equations using repeated ANOVA and post hoc test, demonstrate that the mean absolute deviations for the residuals obtained from equations (2), (3) and (4) were not significantly different from each other, though they were significantly different from equations (1). 
- Equations for prediction of TSD in burn cases:

Table (9): Regression equation for prediction of TSD in burn cases.

\begin{tabular}{|c|c|c|c|c|c|c|}
\hline no & Equation & $\mathbf{R 2}$ & $\begin{array}{l}\text { Adjusted } \\
\quad \text { R2 }\end{array}$ & \begin{tabular}{|c|}
$\%$ \\
Shrinkage
\end{tabular} & $\mathbf{F}$ & $\mathbf{P}$ \\
\hline 1 & TSD $=-3.451+($ Vitreous K x2.016 $)$ & 0.922 & 0.920 & 0.2 & 564.083 & $<0.001 *$ \\
\hline 2 & $\begin{array}{c}\text { TSD }=-4.023+(\text { Vitreous K x1.960 })+ \\
\quad(\text { Rigidity } \times 0.300)\end{array}$ & 0.922 & 0.919 & 0.3 & 277.768 & $<0.001 *$ \\
\hline 3 & $\begin{array}{c}\text { TSD }=-4.000+(\text { Vitreous K x1.761) + } \\
\text { (Rigidity x0.250) + (Corneal opacity } \\
\text { x0.945) }\end{array}$ & 0.925 & 0.920 & 0.5 & 188.304 & $<0.001 *$ \\
\hline 4 & $\begin{array}{c}\text { TSD }=-4.007+(\text { Vitreous K x1.762 })+ \\
(\text { Rigidity x0.249) + (Corneal opacity } \\
\text { x0.943) + (Hypostasis x0.004 })\end{array}$ & 0.925 & 0.918 & 0.7 & 138.159 & $<0.001 *$ \\
\hline
\end{tabular}

* P values for ANOVA test f-test was statistically highly significant at $\mathrm{p}<0.001$

All obtained equations in this table were a highly significant and can predict TSD but with no high different R2. The highest adjusted R2 is for equation 1 and 3 and no high difference for equation 2 and 4 is best cross validates. In the present study, the least percent shrinkage was for equation (1).

Table (10): Mean values and 95\% (CI) of absolute deviation of residual of equation of burn cases

\begin{tabular}{|l|c|c|c|}
\hline \multirow{2}{*}{ Equation } & \multirow{2}{*}{ Mean value of absolute deviation of residual } & \multicolumn{2}{|c|}{ 95 \% CI } \\
\cline { 3 - 4 } & & LL & UL \\
\hline Equation 1 & 2.03 & 1.64 & 2.42 \\
\hline Equation 2 & 2.01 & 1.62 & 2.41 \\
\hline Equation 3 & $\mathbf{1 . 9 7}$ & 1.58 & 2.36 \\
\hline Equation 4 & $\mathbf{1 . 9 7}$ & 1.57 & 2.36 \\
\hline
\end{tabular}

The least mean absolute deviations for the residuals between the actual and the estimated values of TSD were for Equation (3and4) followed by Equation (2). 
Table (11): Pairwise comparisons of the differences between the mean values of the four equations in burn group

\begin{tabular}{|c|c|c|c|c|}
\hline & Equation 1 & Equation 2 & Equation 3 & Equation 4 \\
\hline Equation 1 & & & & \\
\hline Difference value (p) & $-(-)$ & & & \\
\hline Equation 2 & & & & \\
\hline Difference value (p) & $0.015(0.568)$ & - & & \\
\hline Equation 3 & & & & \\
\hline Difference value (p) & $0.061(0.380)$ & $0.047(0.473)$ & - & \\
\hline Equation 4 & & & & \\
\hline Difference value (p) & $0.062(0.377)$ & $0.047(0.469)$ & $0.00(0.474)$ & \\
\hline
\end{tabular}

The mean obtained from equations were not significantly different from each other.

Table (12): Comparison between the two studied groups according to difference of estimated equation

\begin{tabular}{|c|c|c|c|c|}
\hline Estimated equation & $\begin{array}{c}\text { Control cases } \\
(\mathbf{n}=\mathbf{5 0})\end{array}$ & $\begin{array}{c}\text { Burn cases } \\
(\mathbf{n}=\mathbf{5 0})\end{array}$ & $\mathbf{t}$ & $\mathbf{p}$ \\
\hline Difference equation1 & $2.56 \pm 1.94$ & $2.03 \pm 1.37$ & 1.573 & 0.119 \\
\hline Difference equation2 & $1.29 \pm 1.28$ & $2.01 \pm 1.38$ & 2.718 & $0.008^{*}$ \\
\hline Difference equation3 & $1.12 \pm 1.25$ & $1.97 \pm 1.38$ & 3.207 & $0.002^{*}$ \\
\hline Difference equation4 & $1.12 \pm 1.25$ & $1.97 \pm 1.38$ & 3.204 & $0.002^{*}$ \\
\hline $\mathbf{F}(\mathbf{p})$ & $22.090(<0.001)$ & $0.656(0.580)$ & & \\
\hline
\end{tabular}

* $\mathrm{p}$ values for Student t-test statistically significant at $\mathrm{p} \leq 0.05$

As regard to equation 1, no significant difference was found between control and burn cases but a significant difference were found in equation 2, 3and 4 between control and burn cases.

\section{Equations for prediction of TSD were obtained using the $\mathrm{K}+$}

In present study, equations for prediction of TSD were obtained using serum $\mathrm{K}^{+}$ alone (equation 1) and combination of vitreous and serum $\mathrm{K}^{+}$(equation 2) in control and burn cases. In control and burn cases, two obtained equations were highly significant and can predict TSD but with different R2. 
Table (13): Regression equation obtained for prediction of TSD with relation to serum $\mathrm{K}^{+}$and vitreous $\mathrm{K}^{+}$control and burn cases

\begin{tabular}{|c|c|c|c|c|c|c|c|}
\hline cases & & Equation & $\mathbf{R} 2$ & $\begin{array}{l}\text { Adjusted } \\
\text { R2 }\end{array}$ & $\begin{array}{c}\% \\
\text { Shrinkage }\end{array}$ & $\mathbf{F}$ & $\mathbf{P}$ \\
\hline \multirow[b]{2}{*}{ control } & Equation 1 & $\mathrm{TSD}=-5.863+($ Serum K x1.001 $)$ & 0.857 & 0.854 & 0.3 & 288.306 & $<0.001 *$ \\
\hline & Equation 2 & $\begin{array}{c}\text { TSD }=-(6.837)+ \\
\text { (Serum K x }(0.457)+\text { vitreous K x }(1.351)\end{array}$ & 0.916 & 0.912 & 0.4 & 245.629 & $<0.001 *$ \\
\hline \multirow[b]{2}{*}{ burn } & Equation 1 & $\mathrm{TSD}=-13.293+($ Serum K x1.241 $)$ & 0.794 & 0.790 & 0.4 & 185.572 & $<0.001 *$ \\
\hline & Equation 2 & $\begin{array}{c}\mathrm{TSD}=-(9.834)+(\text { Serum K } \\
\mathrm{x}(0.492)+\text { +vitrousK } \mathrm{x}(1.429)\end{array}$ & 0.969 & 0.967 & 0.2 & 725.333 & $<0.001 *$ \\
\hline
\end{tabular}

As regard to control cases, R2 for equations (2) higher than R2 for equation 1 . The least $\%$ shrinkage was for equation 1 and best cross validates. While in burn cases, equation 2 R2 higher than R2for equation 1, and the least \% of shrinkage was for equation 2 and the best cross validates.

Table (14): Mean values and $95 \%$ CI of equation of control and burn cases in relation to serum $\mathrm{K}^{+}$and $\mathrm{VH} \mathrm{K} \mathrm{K}^{+}$.

\begin{tabular}{|c|c|c|c|c|}
\hline cases & \multirow{2}{*}{ Equation } & Mean value of absolute deviation of residual & \multicolumn{2}{|c|}{$95 \%$ CI } \\
\cline { 4 - 6 } & & & LL & UL \\
\hline \multirow{2}{*}{ control } & Equation 1 & 2.95 & 2.40 & 3.50 \\
\cline { 2 - 6 } & Equation 2 & 2.33 & 1.94 & 2.73 \\
\hline \multirow{2}{*}{ burn } & Equation 1 & 3.05 & 2.33 & 3.77 \\
\cline { 2 - 6 } & Equation 2 & 1.28 & 1.03 & 1.53 \\
\hline
\end{tabular}

In control and burn cases, the least mean value of absolute deviations for the residuals between the actual and the estimated values of TSD were for equation 2 .

\section{DISCUSSION}

The study was carried out on 100 adult autopsy cases from the mortuary of medicolegal department of Ministry of Justice, Alexandria, Egypt, with known PMI. The data collected from all autopsy cases were subdivided into two groups; burn groups (50 cases) and the control (non-burn) groups (50 cases).
In the present study, the age of autopsy cases was ranged from 18 to 58 years. Most of the cases were females, in control cases $62 \%$ female and in burn cases $34 \%$ male.

The reported postmortem intervals in the present study ranged from $3.5 \mathrm{~h}$ to $35 \mathrm{~h}$ in control groups with a mean of $(18.54 \pm 9.41)$ and ranged from $5.5 \mathrm{~h}$ to36.0h in burn groups with a mean of 
(19.97 \pm 8.81$)$ with no much difference between two groups.

In the present study, hypostasis was numerically scored into four scores depending on its appearance and movement by thumb pressure where the least score denoted absence of hypostasis and the highest one denoted inability to remove hypostasis by thumb pressure. This was according to Henssge et al., (2000); Honjyo et al., (2005) and Pk et al., (2015).

In control groups, a highly significant correlation was noticed between hypostasis scores and PMI. This result was similar to study done by Prahlow, (2010) and Houck \& Siegel, (2010)

In burn groups no significant correlation was noticed between hypostasis scores and PMI, the hypostasis not recognize and masked or not seen due to severe burns. Cooper, (2006) stated that restriction of the postmortem hypostasis caused by severe burn.

In the current study, a highly significant correlation was noted between PMI and scores of rigor mortis in control and burn groups.

As regard rigor mortis, the results of control cases have some agreement with previous study done by $\mathbf{P k}$ et al., (2015) and have some difference from study of Salam et al., (2012) which have irregular distributions of studied cases in scores of rigor mortis in relation to PMI, this could be explained by the multiple factors that may affect the onset and time sequence of rigor mortis (Nishida, 2005 and Orthmann \& Hess, 2010). And the results of burn cases coincide with results done by Chintalwar et al., (2016) who found that the onset of rigor mortis accelerated by burn death.

According to numerous studies, several hours after death, rigor mortis appears as a stiffening of muscles, with maximum stiffness occurring 12 to 24 hours after death in an average sized adult at an environmental temperature of $70^{\circ}$ to $75^{\circ} \mathrm{F}$. Rigor begins to disappear and generally is gone after variable times, however, the timing of this sequence of events is so variable, and the intensity of rigor may vary depending upon the cause of death (Saukko \&knight 2004a;Wagner, 2005 and Orthmann \& Hess, 2010).

Corneal turbidity is one of the important postmortem changes. The change in corneal turbidity is believed to be due to the change in hydration. The main cause responsible for its swelling and clouding following death is the increased water content in corneal stroma (Fang et al., 2007).

In this study, a highly significant correlation was noticed between scores of corneal turbidity and PMI in burn and control groups, this result was in agreement with previous studies done by Honjyo et al., (2005) and Liu et al., (2008).

On comparison of the three physical postmortem changes in burn groups, corneal turbidity was more strongly correlated with PMI, followed by rigor mortis, and in control groups rigor mortis was more strongly correlated with PMI, followed by corneal turbidity then the hypostasis. It was in some agreement to results of studies done by Balci et al., (2010); Salam et al., (2012) and Pk et al., (2015) who concluded that 
there is a significant relationship between corneal turbidity and postmortem time so corneal turbidity can be used to estimate postmortem interval especially when used along with other postmortem findings.

Vitreous humor is easier to be collected than CSF and changes of its composition more slowly after death than that of CSF and blood; concentration gradients after loss of selective membrane permeability disappear within a few hours in blood, within 15-20 h in CSF and after $120 \mathrm{~h}$ postmortem in VH (Madea, 2005).

The current study demonstrated a highly significant linear relationship between $\mathrm{K}^{+}$level in $\mathrm{VH}$ and PMI in burn and control cases. The least level was found in PMI less than 12 hrs and then it increased gradually in the PMI ranged between 12 hours and 24 hours to reach its highest level in PMI ranged from 24 hours to 36 hours, The $\mathrm{K}^{+}$level in $\mathrm{VH}$ increased in a regular fashion with an increasing PMI. This result was consistent with that obtained by other previous studies (Muñoz et al., 2002; Zhou et al., 2007 and Passos et al., 2009).

Also, this result was in agree to results of study done by Tumram et al. (2011) who found that, there is weak correlation between $\mathrm{VH} \mathrm{K} \mathrm{K}^{+}$and death interval in first $12 \mathrm{hrs}$, which becomes significantly stronger after that. This may be due to biphasic nature of potassium concentration, which rises more rapidly in the first few hours after death.

This could be explained in the light of Jashnani et al., (2010) study, who stated that during life, the $\mathrm{VH} \mathrm{K}^{+}$ concentration is slightly higher than plasma $\mathrm{K}^{+}$because of an active transport of $\mathrm{K}^{+}$across the ciliary body into the posterior chamber and through the anterior capsule of the lens and passive diffusion through the posterior capsule of the lens into the vitreous body. After death, there is a steady $\mathrm{K}^{+}$leak because of the mechanical limits of the membrane. This increase of $\mathrm{VH} \mathrm{K}^{+}$ levels continue with increasing period after death until equilibration with the plasma sets in (Madea et al., 2005).

Different studies reported significant correlation between $\mathrm{K}^{+}$level in $\mathrm{VH}$ and PMI but with different correlation coefficients. This may be explained by difference in the amount of VH sampled. Some collected a limited volume of $\mathrm{VH}$, while others collected all extractable VH (Muñoz et al., 2002; Zhou et al., 2007 and Yogiraj et al., 2008).

On the other hand, in a study done by Lange et al., (1994), who found that, the relationship between $\mathrm{VH} \mathrm{K} \mathrm{K}^{+}$and PMI is not completely linear. This could be due to the wide PMI range studied in their study that was up to $140 \mathrm{~h}$, exceeding the limits of selective membrane permeability in $\mathrm{VH}$.

In the present study, the $\mathrm{VH} \mathrm{K}{ }^{+}$and rate of it is increasing higher in burn than the control cases. This result was similar to study done by Garg et al., (2004) who found that, $\mathrm{K}^{+}$values of burn cases are higher than $\mathrm{K}^{+}$values of the non-burn cases. This could be explained by hyperkalemia that present in severe burns which caused by shift of potassium into the extracellular space (Hollander \& Calvert, 2006 and Adiga et al., 2015). 
Factitious hyperkalemia caused by cellular leakage of endogenous potassium and postmortem hemolysis and postmortem release of intracellular potassium precludes the usefulness of serum. Samples collected too long after death. About $98 \%$ of the body burden of $\mathrm{K}^{+}$presents in intracellular fluid compartment with this gradient being maintained by an active transport mechanism subject to exhaustion soon after death (Singh et al., 2002).

Postmortem loss of the selective membrane permeability makes the diagnosis of serum electrolytes at the moment of death is not possible, so diagnosis of ante mortem electrolyte disturbance very difficult (Madea and Lachenmeier, 2005).

The present study showed that serum $\mathrm{K}^{+}$and rate of it is increasing higher in burn than the control cases, this result could be explained in the light of previous study, who stated that high serum $\mathrm{K}^{+}$in burn cases occurs as result of increased vascular permeability, oozing of plasma from injuries, increased osmotic pressure in burn tissue and cellular edema. $\mathrm{K}^{+}$level increases because of massive tissue necrosis, postmortem hemolysis (Singh et al., 2002 and Adiga et al., 2015).

A highly significant correlation with a linear relationship was noticed between serum $\mathrm{K}^{+}$concentration and PMI in control and burn groups, the serum $\mathrm{K}^{+}$levels increased in a regular fashion with an increasing PMI. This result was similar to results of study done by Singh et al. (2002), who stated that, in first $36 \mathrm{~h}$ after death, there is rapid increase in serum $\mathrm{K}^{+}$and increase with increase time since death. Also, in accordance with other studies done by
Querido, (1991), but in contrast other study done by Hambleton \& Hodgkinson, (1968) who stated that changes occur in blood and cerebrospinal fluid appear to be of limited value in determining the postmortem interval because of the wide variability between individuals.

In the present study, all the studied variables in control groups (corneal opacity, hypostasis, rigor mortis, serum $\mathrm{K}^{+}$and $\mathrm{VH} \mathrm{K}^{+}$) were significantly correlated with PMI, and in burn groups all studied variable were significantly correlated with PMI except hypostasis.

However, the correlation coefficient values were different variables. The highest correlation coefficient in control and burn groups was for $\mathrm{K}^{+}$level in $\mathrm{VH}$, followed by corneal turbidity and serum $\mathrm{K}+$ then rigidity in burn groups, but in control groups the highest correlation coefficient was for $\mathrm{K}^{+}$level in $\mathrm{VH}$ and serum, followed by rigidity then corneal turbidity and lastly hypostasis.

These significant correlations noted between the different variables in the present study; hypostasis, rigidity, corneal turbidity, serum and vitreous $\mathrm{K}^{+}$ levels and PMI provided a theoretical basis on which PMI can be estimated. All the equations obtained in the present study can predict PMI but with different levels of accuracy.

In the current study control cases, equation (2), (3) and (4) (in which multiple regression analysis was employed to estimate PMI using the three physical postmortem changes and $\mathrm{VH} \mathrm{K} \mathrm{K}^{+}$level) have higher level of accuracy than equation (1) (in which $\mathrm{VH}$ $\mathrm{K}^{+}$was employed to estimate PMI alone). These equations have the highest 
level of R2 and adjusted R2 than equation (1), at the same time; these equations have the least percent of shrinkage and the least mean absolute deviation for the residuals. However, there was no significant difference between mean value of absolute deviations for the residuals obtained from equations (2), (3) and (4) were not significantly different from each other, though they were significantly different from Equation (1).

This indicates better accuracy of the combination of physical method and $\mathrm{VH}$ $\mathrm{K}^{+}$concentration for estimation of PMI than $\mathrm{VH} \mathrm{K}^{+}$concentration alone in control cases in the current work. It could be supported by Henssge et al., (2000); Kaliszan et al., (2009); Ahi and Garg, (2011); Salam et al., (2012) and Pk et al., (2015) who stated that estimation of PMI should be based on combined application of different methods in order to increase the overall accuracy. Lange et al., (1994) they stated that, the determination of PMI using postmortem chemistry $\mathrm{VH} \mathrm{K}^{+}$has been difficult due to the effects of other factors and the generally small numbers of cases available to a single investigator.

Honjyo et al., (2005) confirmed that using physical postmortem changes in PMI estimation is usefulness although they are mostly subjective and have a wide variation. On the other hand, the scoring system for physical postmortem changes doesn't require any special instrument for their assessment so it is a simple and accurate method for PMI estimation.

On comparison, the $\mathrm{R} 2$ values of equations obtained from the present study to those of previous studies; with
$\mathrm{VH} \mathrm{K}^{+}$level alone and in combination of physical method, showed higher value of R2 than that resulted from the study conducted by Salam et al., (2012). This result could be attributed to the difference in analytic method and the amount of sample of VH as Salam et al., (2012) collected VH sample $0.1 \mathrm{ml}$ only and potassium was determined in vitreous humor samples using commercial kit potassium.

A complex method for estimation of PMI was developed by Henssge et al., (2000) it based on the nomogram method and completed by other criteria like hypostasis, rigor mortis, mechanical and electrical excitability of the skeletal muscles as well as pharmacological excitability of the pupils. This method was successfully used in cases at the place where the corpse was found. It showed reliable and more precise limitations of the time of death than any single method alone.

Furthermore, Henssge and Madea, (2004) used a combination of body temperature measurements together with the assessment of intensity and movability of hypostasis, development of rigor mortis, assessment of response of skeletal muscles to mechanical and electrical stimuli and the pharmacological reactivity of the pupils. This combination was proved to be more reliable in assessing the time of death much more accurately than any of the previously described methods alone.

In burn cases the accuracy level was obtained from four equations have no much difference as regard to $\mathrm{R} 2$, adjusted R2, and percent of shrinkage and mean absolute deviation for the residuals. At the same time, equation (1) it had the least percent shrinkage and 
equation (1, 3) had high adjusted R2, and equation $(3,4)$ had least mean absolute deviation for the residuals, However, there was no much difference between mean value of absolute deviations for the residuals between the actual and the estimated values of PMI obtained from each of the four equations with no significantly different from each other.

This corroborates, no much differences in accuracy of the combination of physical method and $\mathrm{VH}$ $\mathrm{K}^{+}$concentration for estimation of PMI and $\mathrm{VH} \mathrm{K}^{+}$concentration alone in burn cases (using all the previously described methods for testing the accuracy of the resulted equations). These results have differences from results in control cases and can be explained by the fact that, the death due to thermal burn has effects on the PM changes specially rigor mortis and hypostasis, which not found in control cases (Cooper, 2006 and Chintalwar et al., 2016)

In this study, it was found that, equation 1 which depend on $\mathrm{VH} \mathrm{K}^{+}$ concentration has no significant difference between control and burn cases, but significant differences were found in equation 2, 3 and 4 between control and burn cases which depend on combination of physical method and $\mathrm{VH}$ $\mathrm{K}^{+}$concentration, this indicates that in burn death, estimation of PMI by $\mathrm{VH} \mathrm{K}^{+}$ concentration more better than physical methods which influenced by burn.

In the present study, we mainly concerned to $\mathrm{VH} \mathrm{K}^{+}$concentration and serum $\mathrm{K}^{+}$was taken just for trying to exclude any electrolyte disturbance that may occur in severe burn cases, but we found that regression equations for prediction of PMI were obtained using the serum $\mathrm{K}^{+}$in control and burn cases with high accuracy level where $\mathrm{R} 2=($ $0.857,0.794)$ adjusted $\mathrm{R} 2=(0.854,0.790)$ percent shrinkage $=(0.4 \%, 0.4 \%)$ and mean absolute deviation for the residuals $=(2.95,3.05)$ respectively. The accuracy level was obtained from this equation can be improved and increased by combination of serum and vitreous $\mathrm{K}^{+}$in control and burn cases with high accuracy level where R2 $=(0.916,0.969)$ adjusted $\quad \mathrm{R} 2=(0.912,0.967) \quad$ percent shrinkage $=(0.3 \%, 0.2 \%)$ and mean absolute deviation for the residuals $=(2.33,1.28)$ respectively.

This result is consistent with that obtained by previous studies as corroborating evidence, estimation of the PMI can be from serum $\mathrm{K}^{+}$ concentration equation but more care has to be taken in future study regarding the environmental temperature and up to some extent for the cause of death (Singh et al., 2002).

In contrast to studies of the extensive animal-based work done by Querido, (1990) who found that it is difficult to assess using the postmortem blood samples because of the redistribution of chemicals and electrolytes dissolved within, the loss of cellular integrity and the absence of energy-dependent transmembranous transportation.

\section{CONCLUSION}

- To conclude, the empirical evidences of the current study indicate the usefulness of the relationship between vitreous and serum $\mathrm{K}^{+}$ concentration with TSD in severe burn deaths. This should enable the forensic pathologist to improve accuracy in estimating the death interval in unwitnessed deaths 
- Furthermore, the scoring method for the postmortem changes alone was proved to be less valuable in TSD estimation in a case of severe burn death as they are influenced by burn.

- The formula calculated from the current study could prove to be increasingly appropriate in the future as it is based on a more recent study and more reliable tests

\section{RECOMMENDATION}

- More care has to be taken in future studies regarding the environmental temperature and up to some extent for the cause of death.

- Further research is suggested to study the relation of chemical and physical postmortem changes to other causes of death with larger sample size and longer postmortem interval.

\section{ACKNOWLEDGMENT}

Our deep gratitude and thanks to all staff members in Alexandria Department of Forensic Medicine, Ministry of Justice, Egypt, for their great help and cooperation in collection of data for this study. We would like to extend our thanks to all of the staff members in Forensic Medicine \& Clinical Toxicology Department, Faculty of Medicine, Benha University, for their help \& cooperation

\section{REFERENCES}

Adiga, U., \& Adiga, S. (2015): Biochemical Changes in Burns. International Journal of Research Studies in Biosciences (IJRSB), 3(7): 88-91.

Afify, M. M., Mahmoud, N. F., Abd El Azzim, G. M., \& El Desouky, N. A. (2012): Fatal burn injuries: A five year retrospective autopsy study in Cairo city, Egypt. Egyptian Journal of Forensic Sciences, 2(4): 117-122.

Ahi, R. S., \& Garg, V. (2011): Role of vitreous potassium level in estimating postmortem interval and the factors affecting it. Journal of Clinical and Diagnostic Research, 5(1): 13-15.

Balci Y, Basmak H, Kocaturk BK, Sahin A, Ozdamar K. (2010): the importance of measuring intraocular pressure using a tonometer in order to estimate the postmortem interval. Am J Forensic Med Pathol, 31(2): 151-55.

Chintalwar, R. S., Gajbhiye, S. K. M., \& Dhawane, S. G. (2016): Estimation of Time Since Death From Rigor Mortis. Prof. RK Sharma, 10(1): 1197.

Church, D., Elsayed, S., Reid, O., Winston, B., \& Lindsay, R. (2006): Burn wound infections. In:Clinical Microbiology Reviews, 19(2): 403-434.

Cooper, P. N. (2006): Burn injury. In :Essentials of Autopsy Practice. Spirnger: $215-232$

Fang, Dong, Y R Liang, and Hu Chen. (2007): The Advance on the Mechanism of Corneal Opacity and Its Application in Forensic Medicine. Forensic Sci Technol, 2: 36-38.

Garg V, Oberoi SS, Gorea RK, Kaur K.(2004): Changes in the levels of vitreous potassium with increasing time since death. JIAFM, 26(4): 136-9. 
Gilbert-Barness, E., Debich-Spicer, D. E., \& Steffensen, T. S. (2005): Handbook of pediatric autopsy pathology. Totowa,New jersy: Humana Press:471-498.

Hambleton, J., \& Hodgkinson, A. (1968): Post-Mortem Changes in Blood Electrolytes with Particular Reference to Calcium. Proceedings of the Association of Clinical Biochemists, 5(3): 77-78.

Henssge C, Althaus L, Bolt J, Freislederer A, Haffner HT, Henssge CA, Hoppe B, Schneider V. (2000): Experiences with a compound method for estimating the time since death. II. Integration of non temperature based methods. Int J Legal Med ,113(6): 320-31.

Henssge, C., \& Madea, B. (2004): Estimation of the time since death in the early post-mortem period. Forensic Science International, 144(2-3): 167-175.

Herndon, D. (2012): Chapter 4: Prevention of burn injuries. Total Burn Care ( $4^{\text {th }}$ Ed.). Edinburgh: Saunders, 46.

Hess KM, Orthmann CH. (2010): Death investigations. In: Hess KM, Orthmann $\mathrm{CH}$, eds. Criminal investigation. 9th ed. Canada: Delmar Cengage Learning : 252-91.

Hollander-Rodriguez, J. C., \& Calvert Jr, J. F. (2006): Hyperkalemia. American Family Physician, 73(2).

Honjyo, K., Yonemitsu, K., \& Tsunenari, S. (2005): Estimation of early postmortem intervals by a multiple regression analysis using rectal temperature and non- temperature based postmortem changes. Journal of Clinical Forensic Medicine, 12(5): 249-253.

Houck M, Siegel J.(2010): Fundamentals of Forensic Science. $2^{\text {nd }}$ ed. London: Elseiver Ltd Academic press: 157- 81 .

Jashnani, K. D., Kale, S. A., \& Rupani, A. B. (2010): Vitreous humor: biochemical constituents in estimation of postmortem interval. Journal of Forensic Sciences, 55(6): 1523-1527.

Karter M J (2006): Fire loss in United States during 2005, abridged report. Quincy (MA): National Fire Protection Association, Fire Analysis and Research Division .

Karter M J (2011): Fire loss in the United States during 2010, Quincy (MA): National Fire Protection Association, Fire Analysis and Research Division.

Kirkpatrick, L. A., \& Feeney, B. C. (2012): A simple guide to IBM SPSS: for version 20.0. Nelson Education.

Kulkarni, C. S., Chavan, G. S., \& Jadhao, A. N. (2016): Medicolegal study of determination of time since death from potassium level in vitreous humour. International Journal of Advances in Medicine, 3(4): 1059-1064.

Lange N, Swearer S, Sturner WQ.(1994): Human postmortem interval estimation from vitreous potassium: an analysis of original data from six different studies. Forensic Sci Int ,66:159-74. 
Liu F, Zhu S, Fu Y, Fan F, Wang T, Lu S.(2008): Image Analysis of the Relationship between Changes of Cornea and Postmortem Interval. PRICAI, LNAI 5351: 998-1003.

Luna, A. (2009): Is postmortem biochemistry really useful? Why is it not widely used in forensic pathology? Legal Medicine, 11, S27-S30.

Madea, B. (2005): Is there recent progress in the estimation of the postmortem interval by means of thanatochemistry? Forensic Science International, 151(2-3): 139-149.

Madea, B., \& Henssge, C. (2003): Timing of death. Forensic Medicine: Clinical and Pathological Aspects: 91-114.

Madea, B., \& Lachenmeier, D. W. (2005): Postmortem diagnosis of hypertonic dehydration. Forensic Science International, 155(1): 1-6.

Madea, B., \& Rödig, A. (2006): Time of death dependent criteria in vitreous humor-accuracy of estimating the time since death. Forensic Science International, 164(2-3): 87-92.

Mahadevan, S. V, \& Garmel, G. M. (2012): An introduction to clinical emergency medicine ( $2^{\text {nd }}$ ed). Cambridge university press:216219.

Mazumdar, A., \& Patowary, A. (2013): A study of pattern of burn injury cases. J Indian Acad Forensic Med, 35(1): 44-46.

Millo, T., Jaiswa, A. K., \& Behera, C. (2008): Collection, preservation and forwarding of biolgical samples for toxicological analysis in medicolegal autopsy cases: A review. J Indian Acad Forensic Med, 30(2): 96-100.

Muñoz Barús JI, Suárez-Peñaranda J, Otero XL, Rodríguez-Calvo MS, Costas E, Miguéns X, Concheiro L. (2002): Improved estimation of postmortem interval based on differential behaviour of vitreous potassium and hypoxantine in death by hanging.Forensic Sci Int ,125(1):67-74

Nishida T.(2005): Cornea. In: Krachmer JH, Mannis MJ, Holland EJ. Cornea Fundmentals, Diagnosis and Mangement. 2nd ed. London: Elseiver Mosby : 3-26.

Passos ML, Santos AM, Pereira AI, Santos JR, Santos AJ, Saraiva ML, Lima JL.(2009): Estimation of postmortem interval by hypoxanthine and potassium evaluation in vitreous humor with a sequential system.Talanta,79(4):1094-9.

Pk, S., Ypg, C., \& Sh, J. (2015): Estimation of Early Postmortem Interval by Multiple Regression Analysis: 2(5).

Pounder DJ (2005): Burns and scalds. In: Encyclopedia of Forensic Sciences, Siegel JA, Saukko PJ and Knupfer GC (Eds.), Elsevier, Michigan, London, 1: 329-335.

Prahlow J.(2010): Forensic Pathology for Police, Death Investigators, Attorneys and Forensic Scientists. New York, Heidelberg, Dordrecht, London: Springer LLC:163-84. 
Querido, D. (1990): Double Logarithmic, Linear Relationship between Plasma Sodium/potassium Concentration Ratio and Postmortem Interval during the 696-H Postmortem Period in Rats. Forensic science international ,44(2-3): 125-34.

Rathinam, R., Singh, A., Goyal, P., Chhoker, V., Jayaprakash, K., Goel, S., \& Chikkara, P. (2015): Vitreous potassium concentration as a predictor of postmortem interval: A cross-sectional study among poisoning and burns cases at a tertiary care center in rural Haryana. Journal of Dr. NTR University of Health Sciences, 4(4): 214.

Salam, H. A., Shaat, E. A., Aziz, M. H. A., MoneimSheta, A. A., \& Hussein, H. A. S. M. (2012): Estimation of postmortem interval using thanatochemistry and postmortem changes. Alexandria Journal of Medicine, 48(4): 335344.

Saukko P, knight B. (2004a): Knight's Forensic Pathology. $3^{\text {rd }}$ ed. London: Edward Arnold LTD (Hodder Headline Group): 52-97.

Singh, D., Prashad, R., Parkash, C., Bansal, Y. S., Sharma, S. K., \& Pandey, A. N. (2002): Linearization of the relationship between serum sodium, potassium concentration, their ratio and time since death in Chandigarh zone of north-west India. Forensic Science International, 130(1): 1-7.

Taha, A. A., Beshr, A. A., Tahseen, H., Nawar, A., \& Darwish, Y. G. (2018): Burns Open Pattern of burns in a population presented to Cairo University hospitals over one year, an epidemiological study. Burns Open, 2(2): 90-93.

Vaitla, P., \& Vani, N. (2017): Correlation between Vitreous Humor Potassium and Time Since Death, 3(4): 16-19.

Wagner S.A.(2005): Color Atlas of the Autopsy. Boca Raton, London, New York, Washington: CRC Press: 1536.

Whitaker, A. P. (2017): Effect of Burning on Minimum Post-Mortem Interval ( minPMI ) Estimation from an Entomological Perspective, 1, 17-31.

Yogiraj, V., Indumati, V., \& Kodliwadmath, M. V. (2008): Study Of Vitreous Humour Electrolytes To Assess The Postmortem Interval And Cause Of Death. Anil Aggrawal's Internet Journal of Forensic Medicine \& Toxicology, 9(2).

Zhou B, Zhang L, Zhang G, Zhang X, Jiang $X$. (2007): The determination of potassium concentration in vitreous humor by low pressure ion chromatography and its application in the estimation of postmortem interval. JChromatogr B Analyt Technol Biomed Life Sci , 852(12):278-81. 


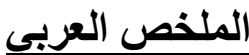

تركيز نسبة البوتاسيوم بالسائل الزجاجى بالعين كمؤشنر لتحديد زمن الوفاة في وفيات الحروق الثديده بمشرحة حامد السيد مصطقى الصواف", مارسيل رمسيس هارون', نيرمين عدلى محمود', عفاف عبد القادر ', رباب فوزى

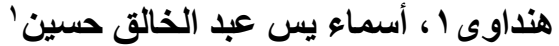

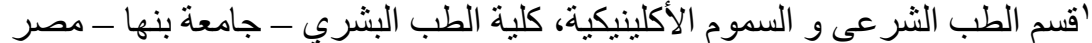

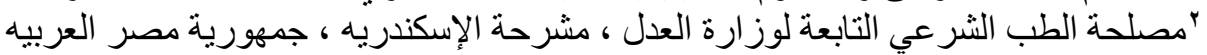

$$
\begin{aligned}
& \text { إن تحديد زمن الوفاة يعد من الامور الهامه في الطب الثرعي و تهدف الدراسة الحالية إلى :- }
\end{aligned}
$$

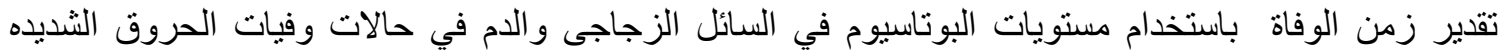

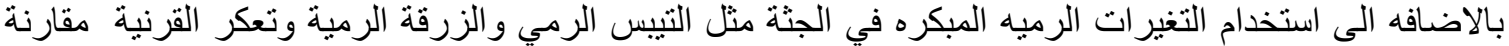

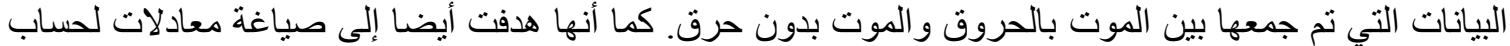

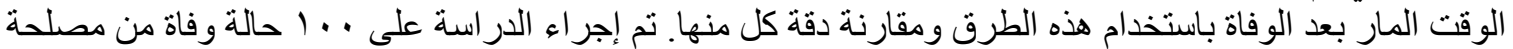

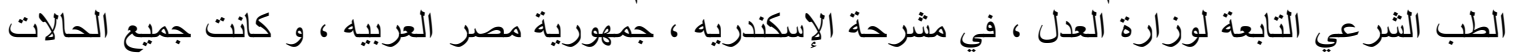

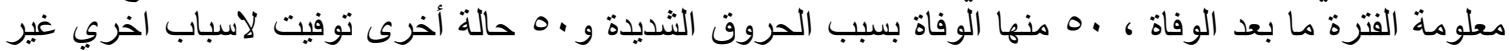

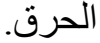

وقد تم استيفاء البيانات التاليه لكل حاله من حالات الاراسه و هي:العمر ، الجنس، سبب الوفاة و الفترة ما بعد الوفاة.

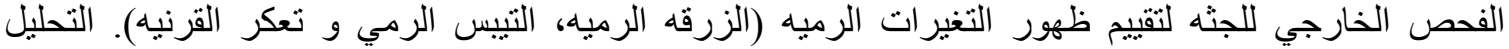

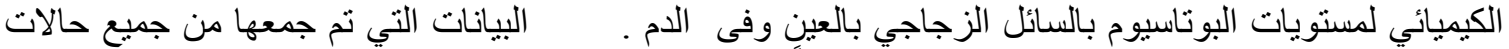

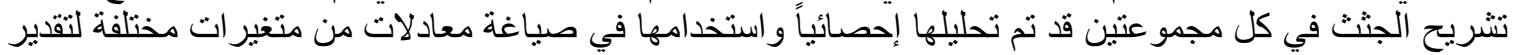
فترة ما بعد الوفاة.

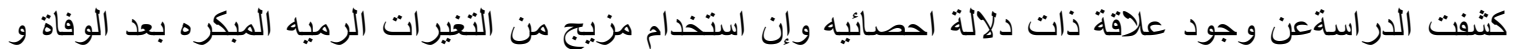

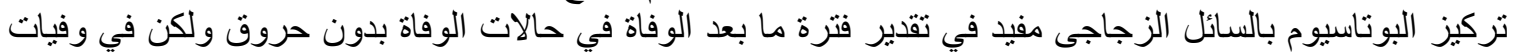

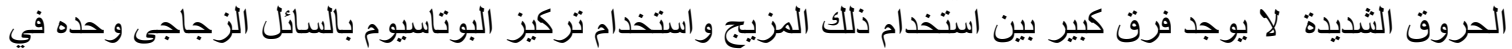

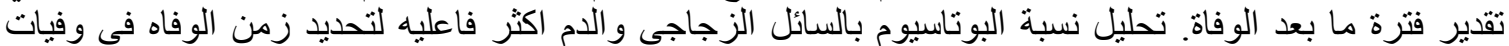
الحروق الثديده من الطرق التقليديه العاديه.

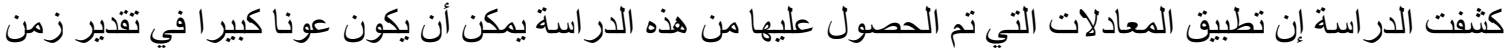

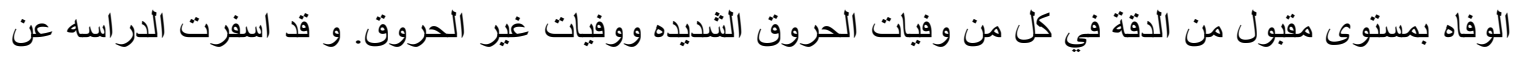

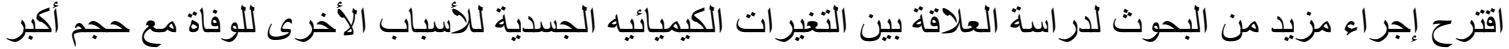
من العينة وفترة أطول بعد الوفاة. 